InOedia $\quad \begin{aligned} & \text { InMedia } \\ & \text { The French Journal of Media Studies }\end{aligned}$

9.1. $\mid 2021$

Film and TV-induced Tourism: Some Contemporary

Aspects and Perspectives

Travel-inspiring Skeletons in Spectre and CocoFilm Tourism and the Día de Muertos in Mexico

\title{
Viola Rühse
}

\section{(2) OpenEdition \\ Journals}

Electronic version

URL: https://journals.openedition.org/inmedia/2985

DOI: $10.4000 /$ inmedia.2985

ISSN: 2259-4728

Publisher

Center for Research on the English-Speaking World (CREW)

Electronic reference

Viola Rühse, "Travel-inspiring Skeletons in Spectre and Coco - Film Tourism and the Día de Muertos in Mexico", InMedia [Online], 9.1. | 2021, Online since 15 January 2022, connection on 08 February 2022. URL: http://journals.openedition.org/inmedia/2985 ; DOI: https://doi.org/10.4000/inmedia.2985

This text was automatically generated on 8 February 2022.

(c) InMedia 


\title{
Travel-inspiring Skeletons in Spectre and Coco - Film Tourism and the Día de Muertos in Mexico
}

\author{
Viola Rühse
}

\section{Introduction}

1 Traditional celebrations of All Souls' Day in Mexico are very different from Halloween in the U.S.A and the All Souls rites in Europe because, in Mexico, Catholic customs are mixed with those of indigenous cultures. ${ }^{1}$ According to popular belief, on Día de Muertos (Day of the Dead), the souls of the deceased pay a visit to their living relatives. ${ }^{2}$ Therefore, families gather at cemeteries on All Saints' Day and All Souls' Day (November 1 and 2), exchange memories, sing, and build ofrendas (altars). These altars are covered with photographs, flowers, and food and commemorate the deceased relatives. The customs pertaining to the celebrations are regionally diverse, and some areas also have celebrations akin to folk festivals.

2 Because of its peculiarity, the Día de Muertos is very characteristic of Mexico. In the $20^{\text {th }}$ century, the Día de Muertos was promoted as a symbol of mexicanidad, i.e., of Mexican national identity. ${ }^{3}$ In 2008, the United Nations Educational, Scientific and Cultural Organization (UNESCO) declared the Día de Muertos an intangible cultural heritage of humanity. In recent years, the Día de Muertos has been the subject of several films. One of the most notable examples, with a large international reach, is the James Bond film Spectre that was directed by Sam Mendes and premiered in 2015. Its opening scenes are located in Mexico City during the Día de Muertos festivities. Another successful example is the animation film Coco produced by Disney-Pixar (Lee Unkrich, 2017) in which the holiday is central to the entire plot. ${ }^{4}$ As explained in the following case study, both films were conducive to the development of a greater interest in Mexico and to creating a positive image of the country in recent years, and 
the present article will therefore discuss how these films benefitted tourism, while also hiding security warnings.

3 Prior to the COVID-19 pandemic that broke out in early 2020, tourism was a growth sector in Mexico which had become a leading tourism destination in Latin America. From 2016 until the outbreak of the pandemic, tourist arrivals were increasing by around $10 \%$ per year. ${ }^{5}$ In 2018, Mexico was the seventh-highest ranked tourism market in the world, and the country had registered 41.3 million international visits while its tourism revenue represented $8.7 \%$ of the gross domestic product (GDP). ${ }^{6}$ The country's Día de Muertos holiday, which takes place from the end of October to the beginning of November each year, is a very attractive period for tourists, especially since the Mexican government has been actively promoting it to foreign visitors since the 1970s. ${ }^{7}$ In 2019, for example, 7.5 million tourists travelled to Mexico for the special celebrations - not just from the nearby U.S.A. but also from Canada, France, and China. ${ }^{8}$

The colourful Día de Muertos festivities can positively counteract the common perception of Mexico as a corrupt and dangerous country. This negative image has especially been linked to the rising murder rate related to the operations of drug cartels in recent years. ${ }^{9}$ Films such as Sicario (Denis Villeneuve, 2015), The Counselor (Ridley Scott, 2013), and Traffic (Steven Soderbergh, 2000) have contributed to this negative image in the ways that they highlighted the violence and danger of Mexican drug cartels. To ensure that Mexico would be portrayed in a particularly positive light in Spectre, private tourism companies and the Mexican government awarded incentives of $\$ 20$ million to the film's producers, ${ }^{10}$ along with special treatment later revealed in leaked e-mails. ${ }^{11}$ The Día de Muertos parade featured at the beginning of Spectre in Mexico City was therefore designed to fulfil some of those demands as it was not occurring at the time of filming and was staged just for the film. ${ }^{12}$ Nevertheless, the city's tourist officials then decided to organise a similar real-life parade in Mexico City to promote tourism during the Día de Muertos festivities. ${ }^{13}$ The film producers of Coco did not receive any financial incentives from Mexico as those of Spectre got, but Coco is inspired by several Mexican customs and locations and conveys a positive image of Mexico. ${ }^{14}$ Mexican and Mexican-American advisors were consulted to ensure an authentic representation of the Día de Muertos and Mexico in Coco. Afterwards, several locations that had inspired the Disney-Pixar film were included in Coco-themed travel tours - for instance by Mexitours - in conjunction with a major public relations campaign by the Consejo de Promoción Turística de México (i.e., Mexico Tourism Board).

The phenomenon of travelling to places featured in films is sometimes known as "filminduced tourism" or "set-jetting," 15 and though film tourism is still a relatively young niche area in tourism overall, it has been increasingly used for advertising tourist destinations and can be considered as an aspect of cultural tourism. ${ }^{16}$ The present article therefore shows how the Mexican government, which traditionally has strongly controlled tourism, is now also adopting new approaches to the industry, including film-induced tourism. First using Spectre and then Coco, this paper analyzes how the Día de Muertos celebrations are portrayed in each film and how a tourism-promoting image of Mexico is generated as a result. For this purpose, a film studies approach has been chosen as a theoretical frame and thus takes into account some of the significant circumstances of the production of the two films. In addition, the touristic products developed from both films - the real-life parade and the tours - are examined. For a 
critical discussion on the commodification of the Día de Muertos in these products, this article also adopts a cultural-historical perspective. ${ }^{17}$ As the case studies are based on two relevant globally-released films, the focus of this film tourism study is more on foreign tourism to Mexico than on local tourist movements-Spectre was supported by the government precisely because of its international visibility. Furthermore, the film tourism products studied have also been promoted internationally, ${ }^{18}$ while the tourism products relating to both films have received a lot of attention from the press, they received less academic interest has been paid to them. ${ }^{19}$

In addition, the general research on Mexican film tourism is still in its infancy, ${ }^{20}$ Tourism studies on the Día de Muertos and the history of Mexican tourism are also informative for this case study, ${ }^{21}$ as is cultural history research on the celebration itself, which includes aspects of tourism and the commercialisation of cultural heritage. ${ }^{22}$ Research on the Día de Muertos and film is therefore insightful for a better understanding of the Día de Muertos representations in Spectre and Coco. ${ }^{23}$

\section{Spectre and the organisation of a new mega-parade in Mexico City}

7 In general, the scenes shown before the credits in a Bond film are very spectacular and the filmmakers invest a great deal of effort to find suitable locations for them. ${ }^{24}$ In the movie Spectre, they show the beginning of James Bond's mission in Mexico City during the Día de Muertos. A parade was held to form a particularly impressive and exotic backdrop for the chase of a villain who is finally overpowered by Agent 007 only after a fight in a helicopter. Afterwards, James Bond flies over the sun-drenched Mexico City skyline to his next destination. For the 10-day shoot of the parade, a particularly large number of extras (1,600 in total) were involved instead of using computer-generated imagery (CGI). Production designer Dennis Gassner collaborated with Mexican artists for the very elaborate costume designs, makeup, and the creation of ten large skeleton models and floats. The preparations for the shooting of the parade scenes in Spectre took six months. The parade, with its many skeletons, looks and its unique and highly memorable scenes is thus ideal as a prelude to the Bond film.

8 The many different locations in Bond films support their varied plots and they capture the audience's attention. Due to their large number of viewers around the world, the Bond films also encourage tourism. ${ }^{25}$ Therefore, to promote a positive image of Mexico City and Mexican culture for tourism in Spectre, the filming was facilitated by a $\$ 20$ million budget from private companies with interests in promoting tourism in Mexico, and support from the Mexican minister of tourism. ${ }^{26}$ Brian Bardwell, a reporter from the independent organisation "Tax Analysts," who had access to internal e-mails leaked from the hack of Sony Pictures in December 2014, drew attention to this. Bardwell also pointed to changes in the script that seemed to be connected with the Mexican incentives, some of which were mentioned in an internal memo from the studio. ${ }^{27}$

9 For example, a portrayal of corrupt Mexican policemen was left out in the final film, even though it was originally in the screenplay, and they were replaced by a "Special Police Force." A Mexican Bond girl was also to be cast, and the producers selected Stephanie Sigman for such a female personification of Mexican attractiveness. According to the agreement, the film also had to feature a four-minute-or-more 
sequence set in the State of Mexico, ${ }^{28}$ which led the producers to opt for a flight over the Mexican skyline and to choose the historic center of Mexico City, with its Zócalo square and the Gran Hotel Ciudad decorated in Art Nouveau style.

The filmmakers most probably selected the Día de Muertos as a backdrop because it is so characteristic of Mexico and has been promoted as an expression of mexicanidad. It also allows the incorporation of sensational scenes, especially when the parade with detailed costumes and floats is integrated. The parade and the large crowds are shown from various perspectives: from up close, from the roof, and with aerial shots. The helicopter flight also integrated aerial shots of the Mexican skyline into the sequence. This was probably included to obtain increased incentives for showcasing the modern facets of Mexico City, namely $\$ 20$ million instead of the $\$ 14$ million that would have been offered, were it not included..$^{29}$ Mexico could thus be perceived as a cosmopolitan business centre and capital through the prominent Mexican skyline with its many striking skyscrapers seen in the film.

11 Overall, Spectre promoted a favourable image of Mexico. The Latin American country appears positive and unique through the integration of the Day of the Dead scenes. It is presented as a country with a unique cultural heritage that is celebrated in a very contemporary way with a large parade instead of having more traditional but older ceremonies in cemeteries. ${ }^{30}$ The inclusion of the attractive Mexican Bond girl that accompanies Agent 007 on Día de Muertos at the beginning of the film makes the festive atmosphere of the parade seem even more attractive. The beautiful and elaborate costumes of the parade's participants and the finer clothes of the onlookers also suggest that the local population are financially well-off. While the festivities in the film are located in the city centre with its impressively large Plaza de la Constitución surrounded by beautiful old buildings, the skyline with modern skyscrapers provides a contrast to the historic centre. This enables Mexico City to be presented as a city with a rich historic heritage and as a modern metropolis with a contemporary lifestyle and popular amusements. This image in Spectre thus aligns with the branding by the authorities of Mexico City as a cosmopolitan capital that acts as a global business center with a rich post-2010 culture and tradition, ${ }^{31}$ and markedly differs from the frequent negative portrayals of Mexico in other international films featuring drug cartels..$^{32}$ The colourful Día de Muertos parade in Spectre therefore positively counteracts and softens negative images of Mexico. ${ }^{33}$

By providing a prominent location for the opening scenes, Mexico City could become a "Ciudad Bond" (Bond City) and gain positive global visibility. ${ }^{34}$ In fact, in the year after the release of the film, the number of international tourists increased by $9.4 \% .^{35}$ Because the parade in the film was only a fictional event, tourism authorities of Mexico and Mexico City decided to organise a real-life parade in 2016. ${ }^{36}$ The official explanation given was that Mexico's tourism authorities did not want to disappoint the tourists who had seen the parade in Spectre and expected it in reality. ${ }^{37}$ According to a categorization of film tourism provided by Sue Beeton, such a parade can be classified as commercial "on-location" film tourism because it takes place on the filming location of Spectre. ${ }^{38}$

13 A total of 1,000 people - costumed actors, dancers, and acrobats - were involved in staging the real-life 2016 parade. As in the film, floats and giant sculptures were integrated into the parade, and some props from the film, including puppets, marionettes, and costumes, were gifted by the production studio to Mexico City to be used for the real parade. ${ }^{39}$ Various traditional customs of the Día de Muertos were also 
included, such as the tradition of "La Muerte Niña." In this Mexican funeral rite, deceased children are staged in fine clothing and photographed to honour them because they are seen as little angels. ${ }^{40}$ The tradition was interpreted in a modern way in the parade, e.g., adult women with balloons, special dresses, and giant pearl necklaces sat in vintage cars. ${ }^{41}$ The parade lasted four hours following a 3.5-kilometrelong route. It started at the Angel of Independence monument and ended at the Zócalo square shown in Spectre. Restaurants and hotels participated and created their own Día de Muertos altars. International media partnerships were also formed, for instance with the New Yorker, for coverage of the Día de Muertos traditions in Mexico. ${ }^{42}$

There had never been such a parade in Mexico City before, as only a few smaller parades in other Mexican cities had ever been organized during the Día de Muertos festivities. For example, in Aguascalientes, a "Calaveras Parade" had been being held for more than 20 years, ${ }^{43}$ while in San Miguel de Allende, the "La Calaca" festival with a participatory parade had been being organized since $2012 .{ }^{44}$ In general, the Día de Muertos festivities have an exuberant festival-like atmosphere, which has increased in recent years. Inspired by American Halloween practices, a parade of school children was for example organized in Oaxaca in the $1990 \mathrm{~s}^{45}$ The Halloween parades that originated in New York and San Francisco probably also influenced the design of Spectre. ${ }^{46}$ In fact, Halloween traditions have become increasingly blended with Día de Muertos customs in Mexico, ${ }^{47}$ although an increased political connotation can also be observed in recent years, with the effort to distinguish the Mexican celebration from Halloween in the U.S.A., ${ }^{48}$ where Halloween does not involve a commemoration of the deceased ${ }^{49}$ What is more, parades generally have a festival-like atmosphere and can be very secular, ${ }^{50}$ which differs significantly from the more religiously-connoted traditional celebrations in Mexican cemeteries during Día de Muertos. Younger adults from Mexico and abroad can therefore be seen as one of the main target audience groups for the parade. Watching the parade is an ideal activity for short visits to Mexico and is thus particularly well-suited for both Mexicans and US tourists on shorter stays.

However, the parade's organisers were also hoping for an international reach, as stated in a CNN interview by Alejandra González Anaya, who worked as one of the creative directors of the parade: "We're really trying to find a new brand, a new identity, rescuing the old and creating another option for the world to be able to come to our country rather than take a trip to the carnival of Rio or the carnival of Venice. Now there's also the Día de Muertos in Mexico." ${ }^{51}$ It was particularly hoped that the parade in Mexico City would become a destination for tourists from the UK in the years after 2016 as in 2015 the UK was already the third-biggest market for Mexican tourism. ${ }^{52}$ Globally, reports of Día de Muertos activities with the parade were circulated in a 2016 campaign to attract more international visitors for the following year. ${ }^{53}$ With its appealing aesthetic inspired by the Bond film, the parade has indeed gained a lot of international media attention in recent years, which has generally been beneficial for Mexico's image and tourism. ${ }^{54}$ The idea of bringing the parade from the Bond film to reality thus turned out to be very successful in boosting the number of visitors. In 2016, there were 425,000 spectators at the parade and only three years later this had grown to more than 2,000,000..$^{55}$ The growth in the number of tourists in Mexico City around the time of the Día de Muertos celebration was also significant, as before Spectre 
premiered in 2015 , they were 200,000 while in 2019 that number had climbed to $750,000.56$

The extra income generated from the increased number of tourists has also compensated for the losses of about $\$ 20$ million for the 6,500 shopkeepers who had had to close their businesses during the filming of Spectre..$^{57}$ The spectators at such a parade, however, tend to be passive, even though they are invited to dress up in colourful robes and wear skull masks and flower crowns as shown in Spectre. The sale of clothes and make-up generates revenue for local businesses, while the parade offers entertainment and distraction for both foreign and domestic tourists and provides them with an illusion of community. ${ }^{58}$ According to economic geographer David Harvey, such a festival pacifies the local population-in a similar way to the panem et circenses in Ancient Rome. ${ }^{59}$ The real parade also conveys a one-sided positive image of Mexico similar to the one in Spectre - and encourages people to overlook Mexico's social problems through a carefree festive atmosphere instead of, when it comes to the parade's topic of death, a remembrance of the victims of the many homicides connected to the drug cartels. ${ }^{60}$

of course, it is also very striking that the parade in the film is imitated in reality. The props and costumes from the film featured in the parade underline the connection of the event to the film. They are particularly ornate and less folkloric and thus act to set standards for the other floats and costumes not featured in the film. Some floats in the real parade of 2016 were largely based on the ones in Spectre. For example, there were many references to Catrina iconography and Frida Kahlo's dresses in Spectre ${ }^{61}$ that could also be found in the real parade in 2016.

Anthropologist Claudio Lomnitz rightly pointed out that the parade is an "image of Mexican culture, composed with the views of foreigners in mind." ${ }^{62}$ There are in fact many previous examples of a touristification of the Día de Muertos because the Mexican Ministry of Tourism has been promoting these festivities as a major tourist attraction since $1971 .^{63}$ For instance, in rural regions earlier Día de Muertos processions were specially designed to satisfy tourists, and folk dance shows were introduced there from the early 1970s onwards. ${ }^{64}$ The Día de Muertos traditions in Mexico could survive because of touristic appropriation..$^{65}$ But in 2015, the filmmakers of a British-American 007 film, together with Mexican tourism officials, constructed a global view of how the Día de Muertos is celebrated in Mexico City with a very lasting effect. This has raised questions regarding the postcolonial cultural appropriation of the Día de Muertos by foreign film studios. Architect and filmmaker Enrique López Oropeza particularly questions the monumentality of the parade because "it is not too different from the visual candy shown each year by the Macy's Thanksgiving Day Parade in New York."66 The extremely large parade held in Mexico City in 2016 was in fact a response to the growing trend towards "mega-events" 67 designed to satisfy the needs of large tourist masses by providing huge spectacles in the $21^{\text {st }}$ century. ${ }^{68}$ It is also conducive to its success that the parade in Mexico City could build on the popularity of Halloween and carnival parades. As a mega-event should also generate significant media attention, transferring spectacular James Bond film scenes to a real event was of course very beneficial to obtaining a global press response. But Enrique López Oropeza highlights the fact that the large parade formally jeopardises the tradition of the Día de Muertos, which UNESCO proclaimed as being an "Intangible Cultural Heritage of Humanity" in 
2003, and he consequently demands that measures should be taken to safeguard the tradition. ${ }^{69}$

In fact the Mexican tourism sector has received a lot of state support since the $1960 \mathrm{~s},{ }^{70}$ and a famous example alongside the touristic use of the Día de Muertos is the touristic development of the Cancún mega-resort in 1973-74 and the subsequent growth of tourism around the Riviera Maya. ${ }^{71}$ The analysis of the portrayal of Mexico in Spectre and the organisation of a real parade inspired by the film thus show that the Mexican state-led approach to promoting tourism does continue into the $21^{\text {st }}$ century, as was also the case with Coco.

\section{Coco as a boost for tourism to Mexico}

A one-sided positive image of Mexico was also promoted in Disney-Pixar's film Coco. With its joyful colors and exotic environment, Mexico provides an inspiring backdrop, especially for animated films. The digitally-created film Coco is about twelve-year-old Miguel, who is supposed to work as a shoemaker in the family business when he grows up. However, he wants to become a musician, even though music is a taboo subject in his family. When he tries to borrow a guitar for a competition on Día de Muertos, the boy ends up in the City of the Dead. To return from there, he must find his greatgrandfather. Many Mexican locations such as Oaxaca, Santa Fe de la Laguna, or Guanajuato and their culture and traditions inspired the movie, thus giving it a very authentic feeling. ${ }^{22}$

According to the New York Times, Coco represents "perhaps the most sophisticated representation of Mexican popular culture ever produced for the big screen." ${ }^{\prime 3}$ Such an effort to ensure cultural authenticity is unusual for a Disney film, as accusations of racism have frequently been made against Disney when its productions dealt with other cultures or ethnic minorities. ${ }^{74}$ The original title of the film was supposed to be "Día de los Muertos" and Disney-Pixar wanted to have it legally protected. Thus, there has been resistance (despite Disney-Pixar's attention paid to authenticity) to the attempt to trademark "Día de los Muertos", as these festivities are part of Mexico's intangible cultural heritage, and as such are supported by UNESCO in terms of their preservation. Among other things, the well-known cartoonist Lalo Alcaraz voiced his criticism with a cartoon drawing of a skeletal Mickey Mouse monster based on a cinema poster. This "Muerto Mouse" threatens a city in a similar way to Godzilla. The illustration is captioned in red with the warning: "IT'S COMING TO TRADEMARK YOUR CULTURA!"75 In response to the criticism, Disney-Pixar subsequently decided on Coco as the title. To avoid accusations of cultural appropriation and "whitewashing", they also sought advice from, among others, the aforementioned cartoonist Lalo Alcaraz, as well as long-time president of the Mexican Heritage Corporation, Marcela Davison Avilés, and actor Octavio Solis. ${ }^{76}$ This collaboration supported a very convincing integration of local customs into the story of the film, ${ }^{77}$ while in Spectre, on the other hand, the traditional festivities of the Día de Muertos are brought into the contemporary form through a mega-parade.

However, in terms of realism Coco presents us with a family image that is idealistic. Mexican social problems, such as poverty and emigration, are only briefly touched upon, while violence and drugs are left out entirely. ${ }^{78}$ Nevertheless, this was not criticised in the press reviews and the film was very well received, including in China. 
Coco also won two Oscars (Best Animated Film and Best Song) and a Golden Globe in 2018 . With a budget of $\$ 175$ million, the film grossed $\$ 807$ million, making it one of the five highest-grossing Disney-Pixar films of all time. It generated positive global visibility for Mexico, especially by including its Día de Muertos-signature-linked traditions. The film improved the general image of Mexico, which at that time, and in spite of Spectre's campaign, was still problematic because of higher murder rates, general security warnings, and travel warnings for several Mexican states. ${ }^{79}$ Tourism officials were particularly challenged to improve this negative reputation and maintain the remarkable tourism growth of recent years-in 2017, there were nearly 39.3 million tourists in Mexico, $12 \%$ more than in $2016 .{ }^{80}$

The positive image of Mexico in Coco was very favorable for tourism and was further promoted through several PR campaigns. For this purpose, for instance, the "Mexico Tourism Board" worked with communication experts at the company MSL (part of the Publicis Group) to develop several PR measures to promote tourism, ${ }^{81}$ one of which was that the Mexican Department of Tourism, several of its federal state branches, DisneyPixar and tour operators would all work together to develop itineraries to the locations that had inspired Coco. ${ }^{82}$

As Coco is a computer-animated film, it features places that cannot be called exact film locations, but the influences are clearly visible. According to Sue Beeton, Coco itineraries can be categorised as commercial "off-location" film tourism ${ }^{83}$ and its tour could also direct tourist flows. The head of the Department of Tourism in Michoacán presented two routes in October 2018: there was a short tour with visits to nine cities in Michoacán that was organized for the Día de Muertos from 31 October to 4 November, while a longer itinerary with visits to Michoacán, Guanajuato and Oaxaca was organized with the support of the national travel agency Mexitours and could be booked all year long. ${ }^{84}$ Other operators also offered Coco-inspired tours notably targeting families with young children. ${ }^{85}$

To further strengthen the positive image of Mexico, the "Mexico Tourism Board" also launched diversified advertising campaigns in various North American and European cities in the year that followed the release of Coco. ${ }^{86}$ So in 2018 there was a "world tour" of the Día de Muertos and extras dressed as El Charro, Frida, and Diego could be seen at international cities renowned landmarks which included the Eiffel Tower in Paris, Central Park in New York City, and the CN Tower in Toronto. Mexican tourism officials also promoted media outreach in other countries. The main narrative in those promotional efforts was that Mexico is a "colorful magical destination with warmhearted people who share a rich culture and value family relationships," ${ }^{87}$ which is of course aligned with the image of Mexico portrayed in Coco. The PR for the Spectreinspired parade in Mexico City was also included in the campaign because it had developed into an annual event integrated into the Día de Muertos festivities.

The PR advertising campaign for the Día de Muertos in Mexico thus became much more extensive, and almost three times as many articles and more than two-and-a-half times as many social media posts were published in 2018 compared to the previous year..$^{88}$ The attendance at the Día de Muertos festivities in Mexico also increased by $6.3 \%$ in 2018 compared to the previous year ${ }^{89}$ Moralia, the capital of Michoacán, which is the starting point of the short Coco route, also had more visitors with an increase of $50 \%$ in November 2018 and of $20 \%$ for the year of 2019 in comparison to $2018 . .^{90}$ According to the city's tourism secretary, Roberto Monroy García, the tourists came, among others, 
from Korea, Australia, and New Zealand, i.e. even from places where no special advertising campaigns had been carried out, but where coco had raised awareness of Mexico. ${ }^{91}$ Some sites linked to the Día de Muertos tour such as Janitzio are now also overcrowded ${ }^{92}$ but less-visited locations also benefit from the interest that coco has generated.

The Coco-linked campaign promotes cultural trips to Mexico that last several days and encourages tourists to engage with the local traditions. It thus fosters an alternative type of holiday to the tourist-crowded beaches on the Mayan Riviera or the Riviera Nayarit, while favouring a diversification of tourism in Mexico. But with its emphatically positive portrayal of Mexico and its emphasis on family ideology, Coco may also give tourists a false image of some of its locations and their way of life, as was the case with Spectre. The challenge here is to correct misinformation and promote a broader perspective among visitors. ${ }^{93}$

\section{Conclusion}

From 2015 onwards, new approaches such as film tourism have been supported to promote the growth of tourism in Mexico. They have notably relied on films with global reach and featuring the Día de Muertos. Spectre and Coco are such films and both address the Día de Muertos that has been promoted to tourists by the Mexican government since the $1970 \mathrm{~s} .{ }^{94}$ In the Bond film, the Día de Muertos was integrated into the script in connection with financial funding from the government, so that particularly effective 'travel footage' could be produced, and it is particularly striking that Spectre's Halloween-influenced fictional parade resulted in the development of a real parade in Mexico City in the year following the film's release. The event is now organized annually and promotes both national and international tourism to Mexico. ${ }^{95}$ The Coco-based touristic tours were also developed and promoted internationally, and they have facilitated a better understanding of traditional customs than Spectre has and its derived parade. As previously highlighted, the global visibility of both films generated interest and tourists from new markets such as China. Mexico is thus increasingly trying to target new markets, even though it is still visited by many American tourists thanks to its proximity with the U.S.A.

This case study also shows that the Día de Muertos is a good festivity to counteract the negative press regarding the violence in Mexico, which continues to pose a significant challenge to the growth of tourism. ${ }^{96}$ The state-led approach for promoting tourism, which is characteristic of Mexico, has thus continued into the $21^{\text {st }}$ century. As a consequence, new areas such as film tourism are increasingly being supported to promote Día de Muertos, especially when the films have a global reach. It has also had consequences on tourism products, and the newly established parade in Mexico City on the occasion of Día de Muertos illustrates the increasing relevance of mega-events for tourism before the outbreak of the COVID-19 pandemic.

While the influence drawn from American Halloween parades enhances its popularity, the aesthetic coined by the elaborate Spectre film design facilitates gaining a global media outreach. In the computer-animated film Coco, a nostalgic family ideal is central to the story. Such society-stabilising mythology in a high-tech animation film from Pixar Studios, ${ }^{97}$ in combination with colourful Mexican traditions from different locations, has supported the development of an attractive image of the country, which 
could also serve to 'mask' security warnings for tourists. Thus, Coco has been wellsuited to encourage more tourists to make tours to selected locations in Mexico and has also promoted a further commodification of the Día de Muertos while simultaneously contributing to a positive image of Mexico, even though Enrique López Oropeza appealed to filmmakers to reflect on their power to change "hundreds of years' worth of traditions," ${ }^{98}$ something Mexican tourism officials must recognise as it is also their responsibility to preserve the Día de Muertos as cultural heritage.

It remains to be seen how film tourism to Mexico will develop in the coming years. Under the government of Andrés Manuel López Obrador, as of 1 December 2018, the focus of state tourism promotion has significantly changed, among other things to finance the Tren Maya, a new 1,525-kilometre railway connection. In 2020, the big parade in Mexico City had to be cancelled because of the COVID-19 pandemic, and in Michoacán they tried to prevent crowds from gathering. As a result, only $30 \%$ of the regular number of tourists came for the Día de Muertos to Janitzio, and the atmosphere was less spectacular than usual as the local customs were more on display in $2020 .{ }^{99} \mathrm{Of}$ course, it is to be hoped for the Mexican economy that the COVID-19 mass vaccination campaign will make it possible for people to travel and participate in large events in a near future, and if such was the case the Día de Muertos events in Mexico could once again be one of those big spectacles gathering thousands of people. The challenge, however, is to impart more cultural and historical knowledge through mega-events and travel tours instead of primarily relying on James Bond sensational film aesthetics and Disney-Pixar saccharine narratives. It should also not be forgotten that Mexico has many other special traditions in addition to the Día de Muertos and that these have not yet been used for (film) tourism but could also be further developed in the future..$^{100}$

\section{BIBLIOGRAPHY}

Adie, Ashton and René G. Cepeda. "Film tourism and cultural performance: Mexico City's Day of the Dead Parade." In Inclusive innovation for enhanced local experience in tourism - Workshop Proceedings, edited by Endrit Kromidha and Sirpan Deesilatham, 33-36. Phuket: University of the Thai Chamber of Commerce and University of Birmingham, 2018.

Agren, David. "Mexico City's James Bond-inspired Day of the Dead parade gets mixed reviews," The Guardian, October 30, 2016. https://www.theguardian.com/world/2016/oct/29/day-of-thedead-parade-james-bond-mexico-city <accessed on January 7, 2021>

Bardwell, Brian. "From Mexico With Love: How Sony Got Millions in Incentives to Rewrite 007 Film." State Tax News and Analysis, (March 9, 2015): 577-578

Bardwell, Brian. “James Bond Producers Offer New Clues On Mexican Incentive.” State Tax News and Analysis, (March 30, 2015): 778-780.

BBC editorial team, "How dangerous is Mexico?" www.bbc.com, February 18, 2020. https:// www.bbc.com/news/world-latin-america-50315470<accessed on May 23, 2021>

Beeton, Sue. Film-Induced Tourism. Clevedon et al.: Channel View Publications, 2005. 
Behlil, Melis, Ignacio M. Sánchez Prado, and Jaap Verheul. “The Dead Are Alive: The Exotic NonPlace of the Bondian Runaway Production." In: The Cultural Life of James Bond: Specters of 007, edited by Jaap Verheul, 81-102. Amsterdam: Amsterdam University Press, 2020.

Berger, Dina and Andrew Grant Wood eds. Holiday in Mexico: Critical reflections on tourism and tourist encounters. Durham: Duke University Press, 2010.

Brandes, Stanley. "El Día de Muertos, el Halloween y la búsqueda de una identidad nacional Mexicana." Alteridades 10/20, (2000): 7-20.

Brandes, Stanley. Skulls to the Living, Bread to the Dead: The Day of the Dead in Mexico and Beyond. Oxford: Blackwell, 2006.

Castañeda de la Cruz, Margot. “iLista la ruta de Coco para Día de Muertos! Recorre los nueve pueblos," Chilango, October 25, 2018. https://www.chilango.com/viajes/escapate/ruta-turisticade-coco/ <accessed on January 7, 2021>

Chebulgaeva, Mari. "Digital Day of the Dead to Prevent the Virus Spread," LACRUS, October 10, 2020, https://lacrus.org/2020/10/21/digital-day-of-the-dead-to-prevent-virus-spread/?lang=en $<$ accessed on January 7, 2021>

Chevrier, Marie-Hélène and Chloé Huvet. "From James Bond with love: tourism and tourists in the Bond saga," Via. Tourism review (online), Vol. 14, 2018. http://journals.openedition.org/ viatourism/3083 <accessed on January 6, 2021>

Child, Ben. "Disney drops bid to trademark Day of the Dead," The Guardian, May 8, 2013. https:// www.theguardian.com/film/2013/may/08/disney-trademark-day-dead-festival-pixar <accessed on September 25, 2021>

Cruz Vargas, Julia Sand and Erica Itzel Landa Juárez. "La muerte niña, un ritual funerario olvidado," Antropología. Revista Interdisciplinaria Del INAH 92, (2011): 146-151.

Cußler, Jonas. "Disney und Rassismus-Vorwürfe," TelevIZIon 31, (2018/2): 31-33.

ed/jlw [initials]. "Journalist killings in Mexico worst in a decade," DW.com, November 25, 2020. https://www.dw.com/en/journalist-killings-in-mexico-worst-in-a-decade/a-55728646 <accessed on January 8, 2021>

Dimitriadis, Giorgos. "Immersion through culture: Representations of the 'Day of the Dead' in Film.” Revista Canaria de Estudios Ingleses 81, (November 2020): 61-78.

Editorial team, "Mexico," OECD Tourism Statistics (Database), OECD iLibrary, https://www.oecdilibrary.org/sites/525e83e3-en/index.html?itemId=/content/component/525e83e3-en <accessed on May 23, 2021>

Fitch Solutions team, Mexico Tourism Report: Q3 2020, London: Fitch Solutions 2020.

García, Jacobo. "Mexico looks to James Bond to end tourism blues," El País International, October 31, 2016. https://english.elpais.com/elpais/2016/10/31/inenglish/1477912427_497507.html $<$ accessed on September 26, 2021>

Garcia, Viri. "Films About Mexico Should Stop Focusing on Día de los Muertos and Drugs," The Cornell Daily Sun, January 23, 2018. https://cornellsun.com/2018/01/23/guest-room-films-aboutmexico-should-stop-focusing-on-dia-de-los-muertos-and-drugs/ <accessed on January 7, 2021> Giardina, Carolyn. “'Coco': How Pixar Brought Its "Day of the Dead” Story to Life," The Hollywood Reporter, December 12, 2017. https://www.hollywoodreporter.com/movies/movie-features/cocohow-pixar-brought-day-dead-story-life-1065932/ <accessed on September 25, 2021> 
Gotham, Kevin Fox. "Theorizing urban spectacles. Festivals, tourism and the transformation of urban space," City 9/2, (July 2005): 225-246.

Harvey, David. “Voodoo cities.” New Statesman and Society 1, (30 September 1988): 33-35.

Hernández García, Sandra. "Tras filmación, DF se recuperará al ser Ciudad Bond," El Universal, April 1, 2015. http://archivo.eluniversal.com.mx/ciudad-metropoli/2015/perdidas-por-

filmacion-spectre-quedaran-contrarrestadastorruco-1089305.html <accessed on January 7, 2021>

Hoops, Joshua F. and Jolanta A. Drzewiecka. "Critical Perspectives Toward Cultural and Communication Research." In: Oxford Research Encyclopedia of Communication, Online Publication, New York: Oxford University Press, 2017.

Israel, Juliane. Baedeker Reiseführer Mexiko. Ostfildern: Mair Dumont, 2019.

Journal of Hispanic Policy - editorial team, "Coco and Tourism in Mexico." Journal of Hispanic Policy Online - Feature Articles. https://hjhp.hkspublications.org/2018/02/23/coco-and-tourismin-mexico/ <accessed on September 24, 2021>

Kaneva, Nadia. "Between Brand Utopias and Lived Experience." in Inclusive Place Branding: Critical Perspectives on Theory and Practice, edited by Mihalis Kavaratzis, Massimo Giovanardi, and Maria Lichrou, 182-190. London: Routledge, 2018.

Kemper, Robert V. “Tourism”. In Oxford Encyclopedia of Mesoamerican Culture, vol. 3, edited by David Carrasco, 250-252. New York: Oxford University Press, 2001.

Kingma, Amarens. Day of the Dead. An analysis of the impact of cinema on the touristic promotion (offer) and tourist experience (reception) of the Day of the Dead in Mexico. Master Thesis. Nijmegen: Radboud University, 2019.

Lara, Josimar. “Lista, la ruta turística de Coco en Michoacán,” MiMorelia.com, October 20, 2018. https://www.mimorelia.com/lista-la-ruta-turistica-de-coco-en-michoacan/ <accessed on September 24, 2021>.

Lomnitz, Claudio. "Un suicidio de la muerte mexicana," La Jornada, November 2, 2016. https:// www.jornada.com.mx/2016/11/02/opinion/016a2pol <accessed on January 7, 2021>

López Oropeza, Enrique. "The cultural appropriation of the Day of the Dead by foreign studio films.” Tensões Mundiais 16, no. 31, (2020): 249-255.

Marchi, Regina M. Day of the Dead in the USA: The Migration and Transformation of a Cultural Phenomenon, New Jersey: Rutgers University Press, 2009.

Martínez Elorriaga, Ernesto. “Janitzio, con magra concurrencia en la Noche de Muertos," La Jornada, November 2, 2020. https://www.jornada.com.mx/ultimas/cultura/2020/11/02/janitziopracticamente-desierta-en-la-noche-de-muertos-9779.html <accessed on January 6, 2021>

Mexicanist editorial team. "Coco Route: the new tourist route in Mexico that emerged thanks to Disney," Mexicanist, January 29, 2020. https://www.mexicanist.com/l/coco-route/ <accessed on January 6, 2021>

Mexico Tourism Board. "Mexico Tourism Board Celebrates Day of the Dead," Cision PR Newswire, October 24, 2016. https://www.prnewswire.com/news-releases/mexico-tourism-boardcelebrates-day-of-the-dead-300350057.html <accessed on January 7, 2021>

Mexico Tourism Board. "Mexico Tourism Board Announces Strategic Marketing Programme Targeting UK Growth," Cision PR Newswire, November 8, 2016. https://www.prnewswire.co.uk/ news-releases/mexico-tourism-board-announces-strategic-marketing-programme-targeting-ukgrowth-600372481.html <accessed on January 7, 2021> 
MSL (New York, USA). “Celebrating Day of the Dead to Bring Life to Mexico's Tourism Industry," award submission materials for The International Business Awards, 2019. https://stevieawards.com/ $\mathrm{iba/msl-travel-tourism-campaign} \mathrm{<accessed} \mathrm{on} \mathrm{January} \mathrm{7,} \mathrm{2021>}$

Mulder, Nanno (coord.). "The impact of the COVID-19 pandemic on the tourism sector in Latin America and the Caribbean, and options for a sustainable and resilient recovery," International Trade series 157 (LC/TS.2020/147), Santiago, Economic Commission for Latin America and the Caribbean (ECLAC), 2020.

Naranjo, José Carlos. "Una ruta para descubrir el Día de Muertos a través de 'Coco'," Crónica Directo, October 31, 2018. https://cronicaglobal.elespanol.com/cronica-directo/curiosidades/ ruta-dia-muertos-coco-mexico_195499_102.html <accessed on January 7, 2021>

Neef, Andreas. Tourism, Land Grabs and Displacement: The Darker Side of the Feel-Good Industry. Abingdon / New York: Routlege, 2021.

Oliveira, Nelma Gusmão de Mega-events, city and power. Abingdon / New York: Routledge, 2021.

Ordóñez Angulo, Emmanuel. “The Politics of Parading," BLARG Blog - Los Angeles Review of Books Blog, November 21, 2016. http://blog.lareviewofbooks.org/essays/politics-parading/ <accessed on January 7, 2021>

Paz, Octavio. El laberinto de la soledad [1950]. Mexico: Fondo de cultura económica, 1998.

Pittman, Veronique. "Celebrating the Dead in Modern Ways," Forbes, November 1, 2012. https:// www.forbes.com/sites/fathom/2012/11/01/la-calaca-festival-san-miguel-de-allende-mexico/? $\mathrm{sh}=52 \mathrm{~d} 054 \mathrm{~d} 23 \mathrm{ad} 2<$ accessed on September $24,2021>$

Racioppi, Linda and Colleen Tremonte. "Geopolitics, Gender, and Genre: The Work of Pre-Title/ Title Sequences in James Bond Films." Journal of Film and Video 66, no. 2, (May 2014): 15-25.

Rühse, Viola. "Sergej Eisensteins mexikanische 'danse macabre' in den filmtheoretischen Entwürfen von Siegfried Kracauer." In Totentanz in Film, Fotografie und Kunst, edited by Jessica Nitsche, 47-68. Berlin: Neofelis, 2015.

Rühse, Viola. Film und Kino als Spiegel. Siegfried Kracauers Filmschriften aus Deutschland und Frankreich. Leipzig: Academy of Fine Arts, PhD thesis, 2020.

Schatzberg, Simon. "Mexico City's New Day of the Dead Parade is Based on a James Bond Film," Atlas Obscura, November 11, 2016. https://www.atlasobscura.com/articles/mexico-citys-new-dayof-the-dead-parade-is-based-on-a-james-bond-film <accessed on January 7, 2021>

Scott, Chris. "Day of the Dead parade -- life imitates art," CNN, October 28, 2016. http:// edition.cnn.com/travel/article/mexico-city-day-of-the-day-parade/index.html <accessed on September 24, 2021>

Speakman, Mark. "Dark tourism consumption in Mexico City: a new perspective of the thanatological experience." Journal of Tourism Analysis: Revista de de Análisis Turístico 26, no. 2, (2019): 152-168.

Stanglin, Doug. "Mexico travel warning: U.S. urges citizens to avoid 5 Mexican states," USA Today, January 11, 2018. https://eu.usatoday.com/story/news/world/2018/01/11/mexico-travelwarning-u-s-urges-citizens-avoid-5-mexican-states/1023620001/ <accessed on January 7, 2021>. Stavans, Ilan. “'Coco' and Mexico's Infatuation With the Afterlife," The New York Times (International Edition), December 12, 2017. 
Tomala, Karolina and Florence Faber. "Film tourism," in The Long Tail of Tourism - Holiday Niches and their Impact on Mainstream Tourism, edited by Alexis Papathanassis, 149-158. Wiesbaden: Gabler Verlag, 2011.

Türcke, Christoph. Erregte Gesellschaft. Philosophie der Sensation. Munich: C.H. Beck, 2012.

Vodopivec, Barbara. Made in Tepito: Urban Tourism and Inequality in Mexico City, Inauguraldissertation, Ludwig Maximilian University of Munich, 2017.

Wyche, Elbert. "Pixar's Lee Unkrich and Adrian Molina on making 'Coco' feel authentic," Screen Daily, November 30, 2015. https://www.screendaily.com/pixars-lee-unkrich-and-adrian-molinaon-making-coco-feel-authentic/5124547.article <accessed on September 25, 2021>

Yucatan editorial team. "40 million tourists visited Mexico in 2017," The Yucatan Times, March 11, 2018. https://www.theyucatantimes.com/2018/03/40-million-tourists-visited-mexico-in-2017/ $<$ accessed on January 7, 2021>

Zimmermann, Stefan. "Reisen in den Film` - Filmtourismus in Nordafrika." In Tourismus - Lösung oder Fluch? Die Frage nach der nachhaltigen Entwicklung peripherer Regionen, edited by Heike Egner, 75-83. Mainz: Geographisches Institut Johannes Gutenberg-Universität Mainz, 2003.

Traffic (Steven Soderbergh, 2000).

The Counselor (Ridley Scott, 2013).

The Book of Life (Jorge R. Gutierrez, 2014)

Sicario (Denis Villeneuve, 2015).

Spectre (Sam Mendes, 2015).

Coco (Lee Unkrich, Adrian Molina, 2017).

\section{NOTES}

1. This article provides a welcome opportunity to analyse the film tourism aspects in detail that I could only discuss briefly in one chapter of my dissertation which will be published by De Gruyter in February 2022.

2. For more general information on the Día de Muertos see Stanley Brandes, Skulls to the Living, Bread to the Dead: The Day of the Dead in Mexico and Beyond (Oxford: Blackwell 2006) and Regina M. Marchi, Day of the Dead in the USA: The Migration and Transformation of a Cultural Phenomenon, (New Jersey: Rutgers University Press 2009).

3. The origin of the Día de Muertos as an expression of mexicanidad dates back to the postrevolutionary period - see Octavio Paz, El laberinto de la soledad [1950] (Mexico: Fondo de cultura económica, 1998), 23.

4. Because of their relevance, Coco and Spectre are also thematised next to ¡Que Viva Mexico! (Sergei Eisenstein, 1931) in: Giorgos Dimitriadis, "Immersion through culture: Representations of the "Day of the Dead" in Film," Revista Canaria de Estudios Ingleses 81, (November 2020): 61-78.

5. Nanno Mulder (coord.), "The impact of the COVID-19 pandemic on the tourism sector in Latin America and the Caribbean, and options for a sustainable and resilient recovery," International Trade Series 157 (LC/TS.2020/147), Santiago, Economic Commission for Latin America and the Caribbean (ECLAC), 2020, 15.

6. Editorial team, "Mexico," OECD Tourism Statistics (Database), OECD iLibrary, https:// www.oecd-ilibrary.org/sites/525e83e3-en/index.html?itemId=/content/component/525e83e3-en $<$ accessed on May 23, 2021>. 
7. Marchi, Day of the Dead in the USA, 126-127.

8. Mexicanist editorial team, "Coco Route: the new tourist route in Mexico that emerged thanks to Disney," Mexicanist, January 29, 2020. https://www.mexicanist.com/l/coco-route/ <accessed January on 6, 2021>.

9. $\mathrm{BBC}$ editorial team, "How dangerous is Mexico?" www.bbc.com, February 18, 2020. https:// www.bbc.com/news/world-latin-america-50315470 <accessed on May 23, 2021>.

10. Brian Bardwell, "James Bond Producers Offer New Clues On Mexican Incentive," State Tax News and Analysis, March 30, 2015, 778-780.

11. There was a hacker attack on Sony Pictures in December 2014 and afterwards internal information were made public via leaked e-mails- Brian Bardwell, "From Mexico With Love: How Sony Got Millions in Incentives to Rewrite 007 Film," State Tax News and Analysis, March 9, 2015, 577-578; Brian Bardwell, "James Bond Producers Offer New Clues On Mexican Incentive."

12. An image of the parade in Spectre can be found here: https://www.imdb.com/title/tt2379713/ mediaviewer/rm3311398144/ <accessed on October 17, 2021>.

13. Only in 2020 could the parade not take place because of the COVID-19 pandemic. - See for images of the real-life parade in Mexico city in 2016: https://www.cntraveler.com/gallery/ mexico-city-holds-first-ever-day-of-the-dead-parade-thanks-james-bond <accessed on October 17, 2021>.

14. Elbert Wyche, "Pixar's Lee Unkrich and Adrian Molina on making 'Coco' feel authentic," Screen Daily, November 30, 2015. https://www.screendaily.com/pixars-lee-unkrich-and-adrianmolina-on-making-coco-feel-authentic/5124547.article <accessed on September 25, 2021>; see also, Carolyn Giardina, “'Coco': How Pixar Brought Its "Day of the Dead" Story to Life," The Hollywood Reporter, December 12, 2017. https://www.hollywoodreporter.com/movies/moviefeatures/coco-how-pixar-brought-day-dead-story-life-1065932/ <accessed on September 25, 2021>. A cinema poster can be found here: https://www.imdb.com/title/tt2380307/mediaviewer/ rm3588392961/ <accessed on October 17, 2021>

15. Sue Beeton, Film-Induced Tourism (Clevedon: Channel View Publications, 2005), and Wioletta Bieńkowska-Gołasa, "Film tourism in the promotion of selected tourist destinations," Acta Scientiarium Polonorum Oeconomia 17.4 (2018): 5.

16. Stefan Zimmermann, “,Reisen in den Film' - Filmtourismus in Nordafrika” in Tourismus Lösung oder Fluch? Die Frage nach der nachhaltigen Entwicklung peripherer Regionen, ed. Heike Egner (Mainz: Geographisches Institut Johannes Gutenberg-Universität Mainz, 2003), 76. See also: Karolina Tomala and Florence Faber, "Film tourism," in The Long Tail of Tourism: Holiday Niches and their Impact on Mainstream Tourism, ed. Alexis Papathanassis (Wiesbaden: Gabler Verlag, 2011), 149-158.

17. In general, film tourism is a relatively novel area of research that covers several disciplines such as tourism sciences, film studies, marketing, and cultural geography, amongst others Bieńkowska-Gołasa, "Film tourism," 5. Critical perspectives towards culture are summarized in: Joshua F. Hoops and Jolanta A. Drzewiecka, "Critical Perspectives Toward Cultural and Communication Research," in: Oxford Research Encyclopedia of Communication, (New York: Oxford University Press, 2017), 36 pages.

18. Domestic tourism is also important for the Día de Muertos festivities, but it cannot be considered due to the limited scope of this article and the available research material with regard to the selected films.

19. The rare scholarly engagements with film tourism and Día de Muertos include Amarens Kingma, Day of the Dead. An analysis of the impact of cinema on the touristic promotion (offer) and tourist experience (reception) of the Day of the Dead in Mexico. Master Thesis (Nijmegen: Radboud University, 2019). 
20. For the state of Mexican research on film tourism in Latin America, see for instance, Rodrigo Tovar Cabañas, José Alfredo Jáuregui Díaz, Shany Arely Vázquez Espinosa, "Influencia del cine en el turismo," El Periplo Sustentable 38, (June 2020): 244.

21. See for instance, Mark Speakman, "Dark tourism consumption in Mexico City: a new perspective of the thanatological experience," Journal of Tourism Analysis: Revista de de Análisis Turístico 26/2 (2019): 152-168 and the contributions on the history of Mexican tourism in Dina Berger and Andrew Grant Wood, eds., Holiday in Mexico: Critical reflections on tourism and tourist encounters (Durham: Duke University Press, 2010).

22. Brandes, Skulls to the Living.

23. Long before Coco and Spectre, for example, Sergei Eisenstein had also thematised the Día de Muertos in iQue Viva Mexico! (1931, unfinished), and a comparison of the cinematic representations of the Mexican celebrations of different directors is illuminating. Eisenstein's film project is analysed in Viola Rühse, "Sergej Eisensteins mexikanische ,danse macabre" in den filmtheoretischen Entwürfen von Siegfried Kracauer," in Totentanz in Film, Fotografie und Kunst, ed. Jessica Nitsche (Berlin: Neofelis, 2015), 47-68; and a comparison is provided in Dimitriadis, "Immersion through culture."

24. The various functions of the pre-title and title sequences of three selected Bond films are analysed in Linda Racioppi and Colleen Tremonte, "Geopolitics, Gender, and Genre: The Work of Pre-Title/Title Sequences in James Bond Films," Journal of Film and Video 66/2 (May 2014): 15-25.

25. Marie-Hélène Chevrier and Chloé Huvet, "From James Bond with love: tourism and tourists in the Bond saga," Via. Tourism review (online), Vol. 14, 2018, 17 pages. http:// journals.openedition.org/viatourism/3083 <accessed on January 6, 2021>.

26. Among the private companies that supported the filming of Spectre in Mexico were Grupo Vidanta and Grupo Alemán - Bardwell, "James Bond Producers Offer New Clues on Mexican Incentive," 778.

27. Ibid., 779.

28. Ibid., 779.

29. Bardwell, "From Mexico With Love," 577.

30. Melis Behlil, Ignacio M. Sánchez Prado, and Jaap Verheul, "The Dead Are Alive: The Exotic Non-Place of the Bondian Runaway Production," in: The Cultural Life of James Bond: Specters of 007, ed. Jaap Verheul (Amsterdam: Amsterdam University Press, 2020), 92.

31. Barbara Vodopivec, Made in Tepito: Urban Tourism and Inequality in Mexico City (Munich: Ludwig Maximilian University of Munich, PhD thesis, 2017), 93.

32. See also Viri Garcia, "Films About Mexico Should Stop Focusing on Día de los Muertos and Drugs," The Cornell Daily Sun, January 23, 2018. https://cornellsun.com/2018/01/23/guest-roomfilms-about-mexico-should-stop-focusing-on-dia-de-los-muertos-and-drugs/ <accessed on January 7, 2021>.

33. Claudio Lomnitz, "Un suicidio de la muerte mexicana," La Jornada, November 2, 2016. https:// www.jornada.com.mx/2016/11/02/opinion/016a2pol <accessed on January 7, 2021>.

34. Sandra Hernández García, “Tras filmación, DF se recuperará al ser Ciudad Bond," El Universal, April 1, 2015. http://archivo.eluniversal.com.mx/ciudad-metropoli/2015/perdidas-porfilmacion-spectre-quedaran-contrarrestadastorruco-1089305.html <accessed on January 7, 2021>. 35. Emmanuel Ordóñez Angulo, "The Politics of Parading," BLARB - Blog// Los Angeles Review of Books Blog, November 21, 2016, http://blog.lareviewofbooks.org/essays/politics-parading/ $<$ accessed on January 7, 2021>.

36. Jacobo García, "Mexico looks to James Bond to end tourism blues," El País International, October 31, 2016. https://english.elpais.com/elpais/2016/10/31/inenglish/ 1477912427_497507.html <accessed on September 26, 2021>.

37. Simon Schatzberg, "Mexico City's New Day of the Dead Parade is Based on a James Bond Film," Atlas Obscura, November 11, 2016. https://www.atlasobscura.com/articles/mexico-citys- 
new-day-of-the-dead-parade-is-based-on-a-james-bond-film <accessed on January 7, 2021>; Nadia Kaneva, "Between Brand Utopias and Lived Experience," in Inclusive Place Branding: Critical Perspectives on Theory and Practice, eds. Mihalis Kavaratzis, Massimo Giovanardi, and Maria Lichrou (London: Routledge, 2018), 183.

38. Beeton, Film-Induced Tourism, 10-11. See also Kingma, Day of the Dead, 18.

39. Mexico Tourism Board, "Mexico Tourism Board Celebrates Day of the Dead," Cision PR Newswire, October 24, 2016. https://www.prnewswire.com/news-releases/mexico-tourism-boardcelebrates-day-of-the-dead-300350057.html <accessed on January 7, 2021>; Enrique López Oropeza, "The cultural appropriation of the Day of the Dead by foreign studio films," Tensões Mundiais 16/ 31 (2020): 253.

40. Julia Santa Cruz Vargas and Erica Itzel Landa Juárez, "La muerte niña, un ritual funerario olvidado," Antropología. Revista Interdisciplinaria Del INAH, 92 (2011).

41. Simon Schatzberg, "Mexico City's New Day of the Dead Parade."

42. Ibid.

43. Juliane Israel, Baedeker Reiseführer Mexiko (Ostfildern: Mair Dumont, 2019), 15.

44. Veronique Pittman, "Celebrating the Dead in Modern Ways," Forbes, November 1, 2012. https://www.forbes.com/sites/fathom/2012/11/01/la-calaca-festival-san-miguel-de-allendemexico/?sh=52d054d23ad2 <accessed on September 24, 2021>.

45. Brandes, Skulls to the Living, 123.

46. Ibid., 133.

47. Ibid., 129.

48. For instance, Brandes addresses the complex issue of Mexican national character: Stanley Brandes, "El Día de Muertos, el Halloween y la búsqueda de una identidad nacional Mexicana," Alteridades, 10/20 (2000): 8.

49. Marchi, Day of the Dead in the USA, 100.

50. David Agren, “Mexico City's James Bond-inspired Day of the Dead parade gets mixed reviews," The Guardian, October 30, 2016. https://www.theguardian.com/world/2016/oct/29/ day-of-the-dead-parade-james-bond-mexico-city <accessed on January 7, 2021>.

51. The interview with Alejandra González Anaya is quoted in Chris Scott, "Day of the Dead parade -- life imitates art," CNN, October 28, 2016. http://edition.cnn.com/travel/article/mexicocity-day-of-the-day-parade/index.html <accessed on September 24, 2021>.

52. Mexico Tourism Board, "Mexico Tourism Board Announces Strategic Marketing Programme Targeting UK Growth," Cision PR Newswire, November 8, 2016. https://www.prnewswire.co.uk/ news-releases/mexico-tourism-board-announces-strategic-marketing-programme-targeting-ukgrowth-600372481.html <accessed on January 7, 2021>.

53. Agren, "Mexico City's James Bond-inspired Day of the Dead parade gets mixed reviews."

54. Schatzberg, "Mexico City's New Day of the Dead Parade is Based on a James Bond Film."

55. The number of spectators refer to all visitors (also locals). - Schatzberg, "Mexico City's New Day of the Dead Parade is Based on a James Bond Film" and Maria Chebulgaeva, "Digital Day of the Dead to Prevent the Virus Spread," LACRUS, October 10, 2020. https://lacrus.org/2020/10/21/ digital-day-of-the-dead-to-prevent-virus-spread/?lang=en <accessed on January 7, 2021>.

56. López Oropeza, "The cultural appropriation of the Day of the Dead by foreign studio films," 253.

57. Schatzberg, "Mexico City's New Day of the Dead Parade is Based on a James Bond Film".

58. See also Kevin Fox Gotham, "Theorizing urban spectacles. Festivals, tourism and the transformation of urban space," City, 9/2 (July 2005): 235.

59. David Harvey, "Voodoo cities," New Statesman and Society 1, (30 September 1988): 33-35.

60. Lomnitz, "Un suicidio."

61. Ashton Adie, René G. Cepeda, "Film tourism and cultural performance: Mexico City's Day of the Dead Parade," in Inclusive innovation for enhanced local experience in tourism - Workshop 
Proceedings, eds. Endrit Kromidha and Sirpan Deesilatham (Phuket: University of the Thai Chamber of Commerce and University of Birmingham, 2018), 34.

62. Ibid.

63. Brandes, Skulls to the Living, 77-92.

64. Marchi, Day of the Dead in the USA, 127.

65. Ibid., 123.

66. López Oropeza, "The cultural appropriation of the Day of the Dead by foreign studio films," 253.

67. To date, mega-events have often been thematised in relation to sporting events, see for example Nelma Gusmão de Oliveira, Mega-events, city and power (Abingdon / New York: Routledge, 2021).

68. The contemporary society that needs such mega-events is analysed in Christoph Türcke, Erregte Gesellschaft. Philosophie der Sensation (Munich: C.H. Beck, 2012).

69. López Oropeza, "The cultural appropriation of the Day of the Dead by foreign studio films," 254.

70. Robert V. Kemper, "Tourism," in Oxford Encyclopaedia of Mesoamerican Culture vol. 3, ed. David Carrasco (New York: Oxford University Press, 2001), 250.

71. Andreas Neef, Tourism, Land Grabs and Displacement: The Darker Side of the Feel-Good Industry (Abingdon / New York: Routledge, 2021), chapter 3.

72. Wyche, "Pixar's Lee Unkrich and Adrian Molina on making 'Coco' feel authentic;" Giardina, “"Coco': How Pixar Brought Its "Day of the Dead" Story to Life."

73. Ilan Stavans, "'Coco' and Mexico's Infatuation With the Afterlife," The New York Times (International Edition), December 12, 2017. Stavan's assertion is problematic because it only refers to American/international films and the Mexican film industry is not considered.

74. Jonas Cußler, “Disney und Rassismus-Vorwürfe," TelevIZIon 31, (2018/2): 31-33.

75. Viola Rühse, Film und Kino als Spiegel. Siegfried Kracauers Filmschriften aus Deutschland und Frankreich (Leipzig: Academy of Fine Arts, PhD thesis, 2020), 265.

76. Rühse, Film und Kino, 266.

77. Ben Child, "Disney drops bid to trademark Day of the Dead," The Guardian, May 8, 2013. https://www.theguardian.com/film/2013/may/08/disney-trademark-day-dead-festival-pixar $<$ accessed on September 25, 2021>.

78. Rühse, Film und Kino, 266-270.

79. Doug Stanglin, "Mexico travel warning: U.S. urges citizens to avoid 5 Mexican states," USA Today, January 11, 2018. https://eu.usatoday.com/story/news/world/2018/01/11/mexico-travelwarning-u-s-urges-citizens-avoid-5-mexican-states/1023620001/ <accessed on January 7, 2021>.

80. Yucatan editorial team, " 40 million tourists visited Mexico in 2017," The Yucatan Times, March 11, 2018. https://www.theyucatantimes.com/2018/03/40-million-tourists-visited-mexicoin-2017/ <accessed on January 7, 2021>.

81. MSL (New York, USA), "Celebrating Day of the Dead to Bring Life to Mexico's Tourism Industry," award submission materials for The International Business Awards, 2019. https:// stevieawards.com/iba/msl-travel-tourism-campaign <accessed on January 7, 2021>.

82. Journal of Hispanic Policy - editorial team, "Coco and Tourism in Mexico," Journal of Hispanic Policy Online - Feature Articles. https://hjhp.hkspublications.org/2018/02/23/coco-and-tourismin-mexico/ <accessed on September 24, 2021>; Josimar Lara, "Lista, la ruta turística de Coco en Michoacán," MiMorelia.com, October 20, 2018. https://www.mimorelia.com/lista-la-ruta-turisticade-coco-en-michoacan/ <accessed on September 24, 2021>.

83. Beeton, Film-induced Tourism, 10-11; see also Kingma, Day of the Dead, 18.

84. Lara, "Lista, la ruta turística de Coco en Michoacán;” Margot Castañeda de la Cruz,. “iLista la ruta de Coco para Día de Muertos! Recorre los nueve pueblos," Chilango, October 25, 2018. https:// 
www.chilango.com/viajes/escapate/ruta-turistica-de-coco/ <accessed on January 7, 2021>. No Coco tours were announced in 2020 due to the COVID-19 pandemic.

85. José Carlos Naranjo, "Una ruta para descubrir el Día de Muertos a través de 'Coco'," Crónica Directo, October 31, 2018. https://cronicaglobal.elespanol.com/cronica-directo/curiosidades/ ruta-dia-muertos-coco-mexico_195499_102.html, <accessed on January 7, 2021>.

86. MSL, "Celebrating Day of the Dead to Bring Life to Mexico's Tourism Industry."

87. Ibid.

88. In total, over 900 articles and 583,000 posts were published worldwide, ibid.

89. Ibid.

90. Mexicanist editorial team, "Coco Route."

91. Ibid.

92. Marchi, Day of the Dead in the USA, 126-127.

93. See also Marchi, Day of the Dead in the USA, 131.

94. Marchi, Day of the Dead in the USA, 126-127.

95. In 2020, however, the parade did not take place because of the COVID-19 pandemic.

96. Fitch Solutions team, Mexico Tourism Report: Q3 2020, London: Fitch Solutions 2020, 21.

97. Rühse, Film und Kino, 265.

98. López Oropeza, "The cultural appropriation of the Day of the Dead by foreign studio films," 254.

99. Ernesto Martínez Elorriaga, "Janitzio, con magra concurrencia en la Noche de Muertos," La Jornada, November 2, 2020. https://www.jornada.com.mx/ultimas/cultura/2020/11/02/janitziopracticamente-desierta-en-la-noche-de-muertos-9779.html <accessed on January 6, 2021>.

100. Garcia, "Films About Mexico."

\section{ABSTRACTS}

In recent years, the Día de Muertos has been the subject of several films. Two of the most notable examples, with a large international reach, are the James Bond film Spectre (Sam Mendes, 2015) and the animation film Coco produced by Disney-Pixar (Lee Unkrich, 2017). This case study analyses how both films were conducive to the development of a greater interest in Mexico and a positive image of the country in recent years that could also serve to mask security warnings for tourists. In addition, the article discusses in detail how these films benefitted tourism.

\section{INDEX}

Keywords: Film tourism, Día de Muertos, Day of the dead, Coco, Spectre

\section{AUTHOR}

\section{VIOLA RÜHSE}

Viola Rühse works as the Head of the Center for Image Science (Bildwissenschaften) and course director at Danube University Krems in Austria. She studied History of Art and German Language 
and Literature at the universities of Hamburg and Vienna and received her $\mathrm{PhD}$ with a dissertation on Siegfried Kracauer's film writings. In addition to film theory, her current research focuses on modern and contemporary art and critical theory. She is also active as a photographer. One of her critical essays was granted the Bazon Brock Essay Award. 